\title{
MINERAL PARAGENESIS AND FLUID INCLUSIONS OF THE BINCANAI EPITHERMAL SILVER-BASE METAL VEIN AT BATURAPPE AREA, SOUTH SULAWESI, INDONESIA
}

\author{
Irzal Nur*1,2, Arifudin Idrus ${ }^{2}$, Subagyo Pramumijoyo ${ }^{2}$, Agung Harijoko ${ }^{2}$, and Akira Imai ${ }^{3}$ \\ ${ }^{1}$ Department of Geological Engineering, Hasanuddin University, Makassar 90245, Indonesia \\ ${ }^{2}$ Department of Geological Engineering, Gadjah Mada University, Yogyakarta, Indonesia \\ ${ }^{3}$ Department of Earth Science and Technology, Akita University, Akita 010-8502, Japan
}

\begin{abstract}
The Baturappe prospect located at southern part of Sulawesi island, Indonesia, is a hydrothermal mineralization district which is characterized by occurrence of epithermal silver-base metal deposits. The mineralization is hosted in basaltic-andesitic volcanic rocks of the late Middle-Miocene Baturappe Volcanics. More than 20 units of quartz - base metal veins are distributed in the area, and one of the most significant is the Bincanai vein. This study is aimed to characterize the mineral paragenesis and to elucidate the physicochemical conditions of the formation of the deposit on the basis of mineral assemblage and fluid inclusion mictrothermometry. Sulphide assemblages in the vein indicate an intermediate sulfidation state epithermal; beside galena and sphalerite as the early stage minerals, chalcopyrite, tennantite, and tetrahedrite are also identified as the later stage. Microthermometric study of fluid inclusions in quartz indicates formation temperature of the vein ranges from about 230 to $280^{\circ} \mathrm{C}$. Histogram of homogenization temperature suggests that there are two generations of hydrothermal fluid responsible for the ore mineralization in the vein; the higher temperature range represents formation temperature of the base metal (galena, sphalerite), while the lower temperature range is correlate with the precipitation of the rest relatively lower temperature
\end{abstract}

*Corresponding author: I. NUR, Department of Geological Engineering, Hasanuddin University, Makassar 90245, Indonesia. E-mail: irzal_nur@yahoo.com sulphides (chalcopyrite, pyrite, tetrahedrite, tennantite, polybasite, and Bi-Ag-Cu-Fe-bearing sulfide). The sequence is also consistent with the mineral paragenetic. The mean of salinity $(2.0-2.5 \mathrm{wt} . \% \mathrm{NaCl}$ eq.) indicates that fluid responsible for the mineralization in the Bincanai vein is relatively low-salinity fluid.

Keywords: epithermal, Bincanai vein, mineral paragenesis, fluid inclusion microthermometry.

\section{Introduction}

The study area is situated in Baturappe area, Gowa Regency, South Sulawesi Province, Indonesia. It lies in the southwesternmost part of Sulawesi island, about $50 \mathrm{~km}$ southeast of Makassar (Ujung Pandang), the capital city of South Sulawesi Province. This area is characterized by occurence of epithermal silver-base metal deposits which are hosted in basalticandesitic volcanic rocks of the late MiddleMiocene Baturappe Volcanics. More than 20 units of quartz veins along with disseminated sulphide and sulphide stringer are distributed around the periphery of a stock intrusion in the study area, hosted in lava and dyke units. Among these, eight significant epithermal mineralizations were recognized: Bincanai vein, Baturappe vein-1, Baturappe vein-2, Bungolo vein, Paranglambere vein, Bangkowa vein, Bangkowa stringer, and Ritapayung dissemi- 
nation. The veins mostly distributed and clustered along the main fault in the study area, the NW-SE trend Bincanai-Baturappe normal fault (Nur et al., 2009).

One of the most significant vein of the deposits is the Bincanai vein which is situated at the northwestern part of the study area, lies in $\mathrm{N} 18^{\circ} \mathrm{W} / 64^{\circ} \mathrm{SW}$ orientation, extends more than $100 \mathrm{~m}$ consistent to the strike, with a thickness range of 13 to $18 \mathrm{~cm}$, and hosted in strongly silisic-altered porphyritic-andesite. Bulk-ore chemical composition of the vein determined by XRF analysis, from three samples, indicates an average of: $\mathrm{Pb} 17.51 \%$, $\mathrm{Zn} 0.35 \%$, Cu $0.66 \%$, Ag $713 \mathrm{~g} / \mathrm{t}$, Bi $308 \mathrm{~g} / \mathrm{t}$, and $\mathrm{MnO} 10.66 \%$ (Nur et al., 2010; 2011). This paper describes a recent study of the Bincanai vein which is aimed to characterize the mineral paragenesis and to elucidate the physicochemical conditions of the formation of the deposit on the basis of mineral assemblage and fluid inclusion mictrothermometry.

\section{Samples and Methods}

In this study, vein samples were collected systematicly from four sampling points in a trench along the Bincanai vein, with $25 \mathrm{~m}$ space (samples: WBC.1A.V, WBC.2A.V, WBC.3A.V and WBC.4A.V). In addition, another two samples from a thinner vein next to the main vein were also collected to be analyzed (samples: TBC.1A and TBC.1B). The mineral assemblages were identified from microscopic observations, Xray diffraction and SEM/EDX analyses. The XRD analysis was conducted using X-ray diffractometer of Rigaku RINT-2100 and the SEM/EDX analysis was conducted using a SHIMADZU SS-550 SEM with a Genesis-2000 EDS. The fluid inclusion study was conducted on quartz from the vein. The quartz samples were prepared in $100 \mu \mathrm{m}$ doubly polished wafers for the analysis. Identification of fluid inclusion in the wafers were conducted using a transmitted light microscopy, and the microthermometry was then performed using a heating-freezing stage of Linkam TH600. All the laboratory works were performed at the Economic Geol- ogy Laboratory, Department of Earth Resources Engineering, Kyushu University, Japan.

\section{Geology and Mineralization Zones}

Regionally, the Baturappe area is located at the southwestern part of the regional geologic map of the Ujung Pandang, Benteng and Sinjai quadrangles, Sulawesi (Sukamto and Supriatna, 1982). A detailed surface geological mapping has been conducted in an area of 1000 ha to study the geological background of the mineralization. The older rock unit broadly distributed in the study area is lava of dominantly basalt and less andesite, mostly porphyritic, with general orientations of $\mathrm{N}(70-80)^{\circ} \mathrm{E} /(18-$ $35)^{\circ}$ SE. Locally, blocks of volcanic breccia are also cropped out. Based on its lithological characteristics, this unit is a member of lava, Tpbl (Sukamto and Supriatna, 1982) which is according to $\mathrm{K}-\mathrm{Ar}$ dating indicates age of 12.38 to 12.81 Ma or late Middle-Miocene (Yuwono et al., 1985; Priadi et al., 1994). The basaltic-andesitic lava which is distributed widely in the study area, is identified as the host rock of the epithermal mineralization. On the north, the lava was intruded by a gabbroic-dioritic stock; and followed by a group of basaltic-andesitic dykes. At least 50 units of dykes with thickness range of $8 \mathrm{~cm}$ to $2.5 \mathrm{~m}$ are cropped-out in the study area, distributed radially centered to the stock, forming a radial swarm of dyke. K-Ar dating on two samples of basalt indicate ages of $7.5 \mathrm{Ma}$ and $6.99 \mathrm{Ma}$, and 7.36 $\mathrm{Ma}$ on gabbro (Sukamto and Supriatna, 1982). The basalticandesitic stock and dykes are interpreted as mineralization-bearing rocks in the study area; this is indicated by the occurence of disseminated ore (i.e., pyrite, chalcopyrite, sphalerite, galena, covellite, magnetite, hematite) recognized in the field and microscopic observations. Due to the orientation of the dykes that are consistent to the trends of the fractures, it is interpreted that the emplacement and distribution of the dykes brought mineralization is highly controlled by geological structures (Nur et al., 2009; Figure 1).

More than 20 units of quartz veins along with disseminated sulphide and sulphide stringer 
NUR et al.

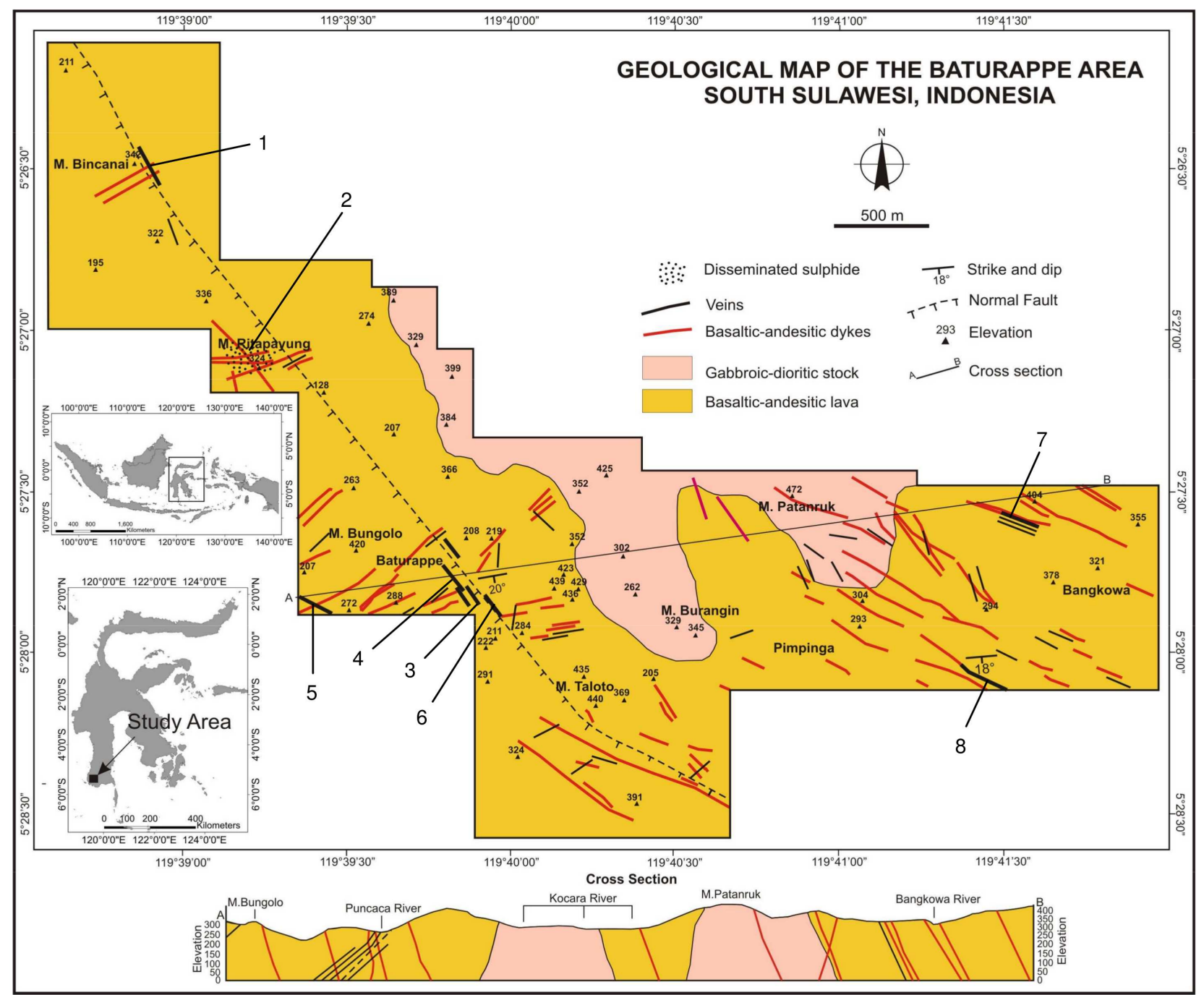

Figure 1: Geological map and distribution of the significant mineralizations in the study area. (1) Bincanai vein (the vein reviewed in this paper). (2) Ritapayung dissemination. (3) Baturappe vein-1. (4) Baturappe vein-2. (5) Bungolo vein. (6) Paranglambere vein. (7) Bangkowa vein. (8) Bangkowa stringer 
are distributed around the periphery of the stock in the study area, hosted in the lava and dyke units. Among these, eight significant mineralizations are distributed in four zones: Bincanai-, Baturappe-, Bangkowa- and Ritapayung zone. The mineralizations include: Bincanai vein, Baturappe vein-1, Baturappe vein2, Bungolo vein, Paranglambere vein (clustered in Baturappe zone); Bangkowa vein and Bangkowa stringer (in Bangkowa zone); and Ritapayung dissemination. The Bincanai vein and Baturappe veins are distributed and clustered along the main fault in the study area, the NW-SE trend Bincanai-Baturappe normal fault; while the Bangkowa- vein and stringer are hosted in NW-SE dykes. Distribution of the mineralizations and orientation of the veins, including the Bincanai vein, are shown in Figure 1 .

\section{Vein Characteristics}

The Bincanai vein is cropped-out at the east slope of Moncong Bincanai, distributed along the steeply southwest-ward dipping main fault in the study area, the NW-SE trend BincanaiBaturappe normal fault (Figure 1); lies in $\mathrm{N} 18^{\circ} \mathrm{W} / 64^{\circ} \mathrm{SW}$ orientation, with a thickness range of 13 to $18 \mathrm{~cm}$, hosted in strongly silisicaltered porphyritic-andesite; the vein extends more than $100 \mathrm{~m}$ consistent to the strike (Figure 2A). This vein displays a typical texture of epithermal vein, symmetric crustiform banding, with succession from outer to center: quartz-, siderite-, sulphide band (Figure $2 \mathrm{~B}-\mathrm{C}$ ). In hand specimen, the siderite band also shows a crustiform banding texture. The sequence is also confirmed by dogteeth-like textute of the siderite band and comb texture of the quartz band. Recrystallization texture of quartz, ghost-sphere texture, is also recognized in quartz-band in one of the sample of the Bincanai vein (sample WBC.3A.V). Other textural characteristic of the Bincanai vein, is coarse- to very coarse-grained crystalline of the quartz; the siderite and galena band are also developed in coarse-grained crystalline (up to $1.2 \mathrm{~cm}$ for galena crystals).

\section{Mineral Assemblage and Paragenesis}

From the six samples, in general, in the hand specimen the sulphide band of the quartzsiderite-sulphide crustiform of the Bincanai vein is dominated by coarse-grained galena (up to $1.2 \mathrm{~cm}$ ) accompanied with less sphalerite, chalcopyrite, and pyrite; the gangue mineral quartz is still observed in this band (Figure 2C). Under microscope, in the gangue minerals (quartz-siderite band) of the vein, galena, sphalerite, chalcopyrite, pyrite and covellite were identified scattered. While in the galena band, beside the gangue minerals quartz, ore minerals identified include coarse-grained galena and sphalerite with subordinate pyrite, tetrahedrite, tennantite, covellite and chalcocite. In addition two unidentified minerals were also observed in a fracture of galena. To identify the unknown minerals, SEM-EDX analysis was conducted on nine spots. The result indicates that one of the mineral is polybasite, which is indicated by significant concentrations of $\mathrm{Ag}$, $\mathrm{Cu}, \mathrm{Sb}$ and $\mathrm{S}$ on five of the spots (averages of Ag 61.63 At.\%, Cu 9.08 At.\%, Sb 4.34 At.\%, S $23.70 \mathrm{At} . \%$ ). The other mineral is a $\mathrm{Bi}-\mathrm{Ag}-\mathrm{Cu}-$ Fe sulphide, which is indicated by significant concentrations of $\mathrm{Bi}, \mathrm{Ag}, \mathrm{Cu}, \mathrm{Fe}$ and $\mathrm{S}$ on the other four spots (averages of Bi $18.30 \mathrm{At} . \%, \mathrm{Ag}$ 12.48 At.\%, Cu 10.93 At.\%, Fe 1.78 At.\%, and S 51.75 ).

In the galena band, from their textural relationships under microscope, it is recognized that galena and sphalerite precipitated in early stage (Figure 3A-B), where galena precipitated first and then followed by sphalerite; this is indicated by the textures shown in Figure 3A where sphalerite overlays galena, and in Figure 3C-D where sphalerite fills the typical triangular pits of galena. Locally finer grains chalcopyrite, pyrite, tetrahedrite and tennantite are distributed on the surface of galena and sphalerite, indicates later stage precipitation (Figure 3A-D). The latest stage ores are minutes polybasite and the Bi-Ag-Cu-Fe sulphide which are occupy fracture of galena and the fringe of chalcopyrite (Figure 3B). Covellite and chalcocite are formed as secondary minerals, replace chalcopyrite (Figure 3E-F). Covellite mostly replace 
NUR et al.
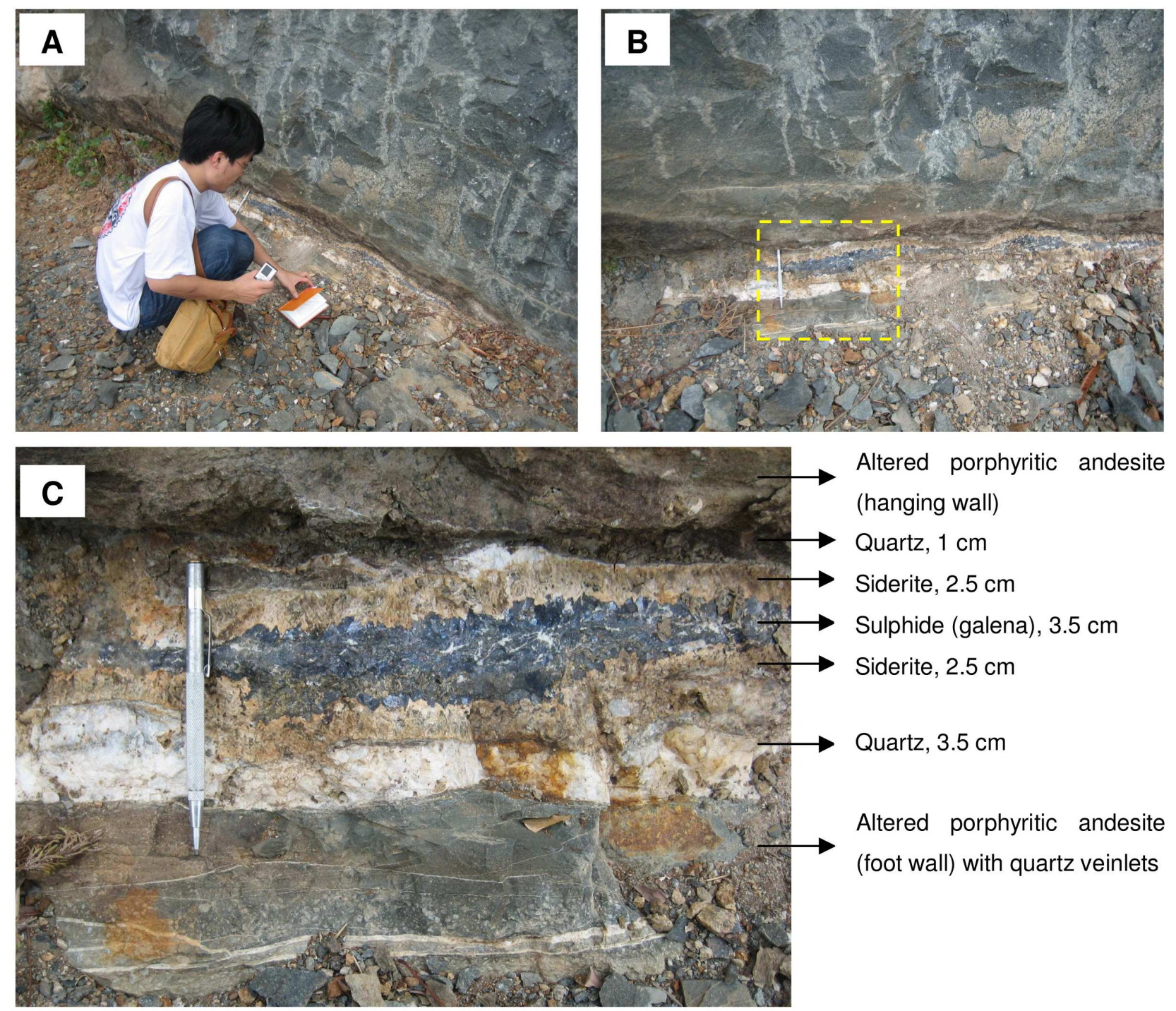

Figure 2: A, B. The N18W/64SW orientation Bincanai vein with a thickness range of 13 to $18 \mathrm{~cm}$, hosted in strongly silisic-altered porphyritic-andesite. C. Magnification view of the vein from Figure $\mathrm{B}$ (yellow dash square) showing a symmetric crustiform banding texture (quartz-siderite-galena) 
the periphery of chalcopyrite forming a reaction rim texture (Figure $3 \mathrm{~F}$ ). Covellite and chalcocite are common supergene products of coppersulphide minerals (Marshall et al., 2004; Pracejus, 2008). Accordingly, the occurrence of covellite and chalcocite in the Bincanai vein is related to subsequent supergene processes.

From XRD analysis, minerals identified in the vein include quartz, siderite, rhodonite, galena, freieslebenite, anglesite, and iodargyrite. Anglesite and iodargyrite are secondary minerals, where anglesite is an oxidation product of lead ores, and iodargyrite is an oxidation product of silver ores (Pracejus, 2008). Thus, similar to covellite and chalcocite, anglesite and iodargyrite are supergene minerals in the Bincanai vein, where anglesite may formed from oxidation of galena or freieslebenite; and iodargyrite from oxidation of polybasite, freieslebenite, or the BiAg-Cu-Fe sulphide. Paragenetic stages of the minerals identified from the Bincanai vein is shown in Table 1 .

\section{Fluid Inclusion Petrography and Mi- crothermometry}

Under microscope, generally the size of fluid inclusion in the quartz of the Bincanai vein ranges from $<5$ to $40 \mu \mathrm{m}$, vary in shape, mostly angular, elongate, and prismatic. At room temperature, all of fluid inclusions showed twophase liquid-vapor (liquid rich) with range of $\mathrm{V} /(\mathrm{V}+\mathrm{L}) 20-50 \%$ (Figure $4 \mathrm{~A}$ ). The inclusions spread parallel and some defining the quartz crystal fringes as a cluster of inclusions and are interpreted as primary inclusions (Figure 4B); less were found trapped along microfractures, which are classified as secondary inclusions (according to the criteria of Roedder, 1979, 1984; Bodnar et al., 1985). Homogenization- and melting temperature were only measured on the primary inclusions.

The fluid inclusion microthermometry results is shown in Table 2 (columns 1-5). The salinity values were determined by converting the melting temperatures (Tm) using the equation of Bodnar (1993). In epithermal deposits, fluid inclusion microthermomety results can be used to estimate formation temperature of the deposit and salinity of the hydrothermal fluid which responsible for the formation of the deposit. The formation temperature is determined by histogram mean (peak) of homogenization temperature. While the salinity of responsible hydrothermal fluid is determined by histogram mean (peak) of salinity (e.g., Bodnar et al., 1985; Etoh et al., 2002; Harijoko et al., 2007). Accordingly, estimation of formation temperature and salinity of responsible hydrothermal fluid of the Bincanai vein is conducted using the histograms of homogenization temperature and salinity. Two pairs of histograms, each represents the main vein (WBC.1A.V) and the thinner vein (TBC.1B) are shown in Figure 5. The results is also shown in Table 2 (columns 6-7).

\section{Discussion and Conclusion}

Based on the mineral assemblages, beside base metal $(\mathrm{Pb}, \mathrm{Zn}, \mathrm{Cu})$, the Bincanai vein is also characterized by occurrence of silver and bismuth mineralization, which is indicated by the presence of polybasite and the Bi-Ag-Cu-Febearing sulphide in the vein. The chemical composition of the vein also confirmed this character (average: Ag $713 \mathrm{~g} / \mathrm{t}, \mathrm{Bi} 308 \mathrm{~g} / \mathrm{t}$ ). The sulphide assemblages in the samples of the Bincanai vein indicate an intermediate sulfidation state. The typical sulphide assemblage of intermediate sulfidation epithermal; tennantite, tetrahedrite, chalcopyrite (Hedenquist et al., 2000; Sillitoe and Hedenquist, 2003) are occurred in the vein (Figure 3, Table 1).

The range of formation temperatures defined from fluid inclusion microthermometry indicates a temperature range of epithermal vein (230-280 $\left.{ }^{\circ} \mathrm{C}\right)$; the textural characteristics of the vein, particularly the crustiform banding and the crystalline texture of the quartz and galena are also supported this figure (Hedenquist et al., 2000; Morrison et al., 1990). From the histogram of homogenization temperatures, sample from the Bincanai main vein (WBC.1A.V) shows two peaks or bimodal mean $\left(230-240^{\circ} \mathrm{C}\right.$ and $250-260^{\circ} \mathrm{C}$, Figure $5 \mathrm{~A}$ ). This may indicates two generations of hydrothermal fluid responsible for the ore mineralization in the vein; the 

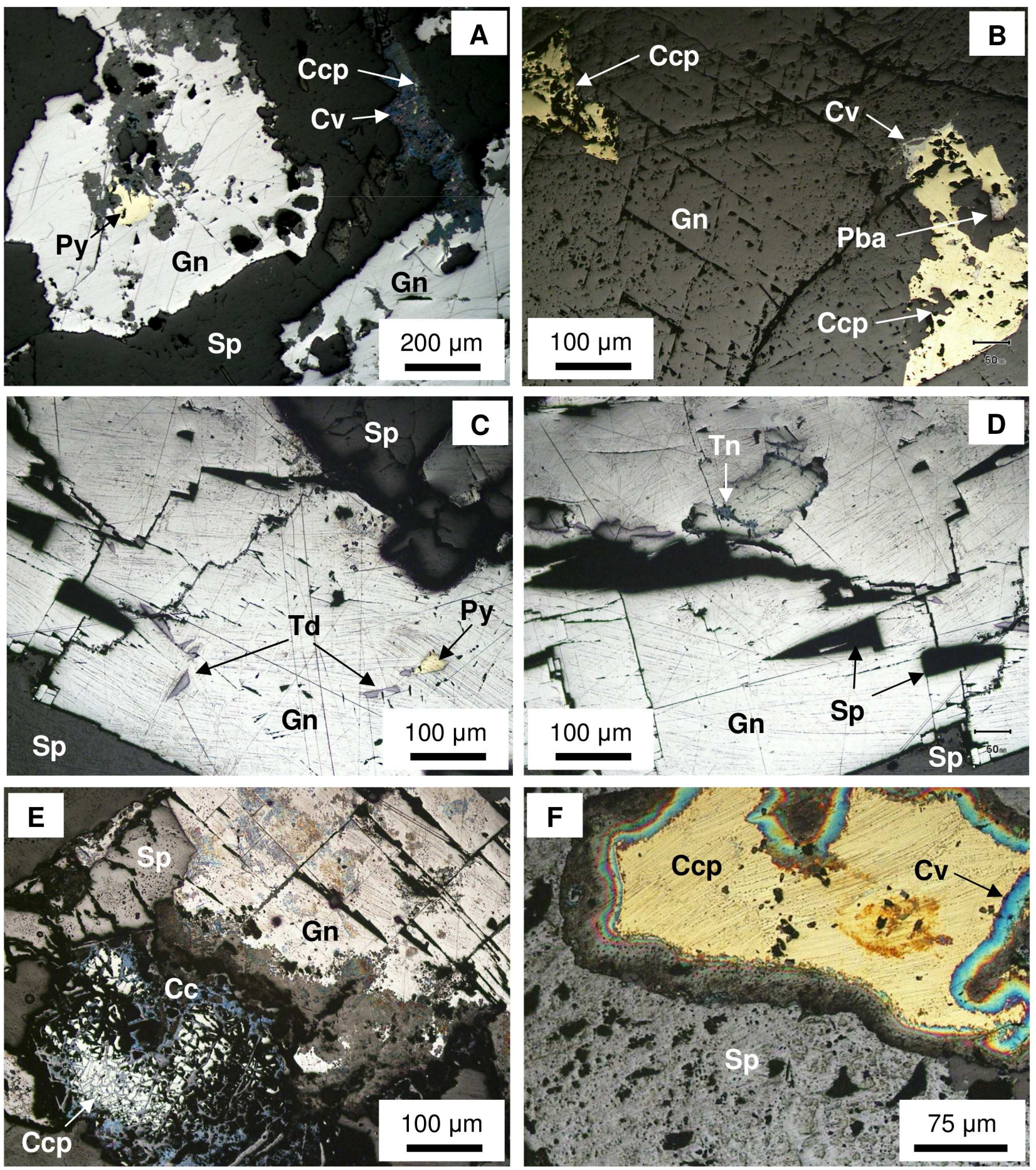

Figure 3: Polished section microphotographs showing the existing ore mineral assemblage and their textural relationships in the sulphide band of the Bincanai vein, as discussed in the text. Abbreviations: Cc: chalcocite, Ccp: chalcopyrite, Cv: covellite, Gn: galena, Pba: polybasite, Py: pyrite, Sp: sphalerite, Td: tetrahedrite, Tn: tennantite 
Table 1: Paragenetic stages of the minerals in the Bincanai vein

\begin{tabular}{|c|c|c|c|}
\hline \multirow{2}{*}{ Minerals } & $\begin{array}{c}\text { Quartz-siderite } \\
\text { band }\end{array}$ & \multicolumn{2}{|c|}{ Sulphide band } \\
\hline & Early stage & Main (hypogene) stage & $\begin{array}{l}\text { Late (supergene) } \\
\text { stage }\end{array}$ \\
\hline \multicolumn{4}{|l|}{ Quartz } \\
\hline \multicolumn{4}{|l|}{ Siderite } \\
\hline \multicolumn{4}{|l|}{ Rhodonite } \\
\hline \multicolumn{4}{|l|}{ Galena } \\
\hline \multicolumn{4}{|l|}{ Sphalerite } \\
\hline \multicolumn{4}{|l|}{ Chalcopyrite } \\
\hline \multicolumn{4}{|l|}{ Pyrite } \\
\hline \multicolumn{4}{|l|}{ Tennantite } \\
\hline \multicolumn{4}{|l|}{ Tetrahedrite } \\
\hline \multicolumn{4}{|l|}{ Freieslebenite } \\
\hline \multicolumn{4}{|l|}{ Polybasite } \\
\hline \multicolumn{4}{|l|}{$\begin{array}{l}\text { Bi-Ag-Cu-Fe } \\
\text { sulphide }\end{array}$} \\
\hline \multicolumn{4}{|l|}{ Anglesite } \\
\hline \multicolumn{4}{|l|}{ Covellite } \\
\hline \multicolumn{4}{|l|}{ Chalcocite } \\
\hline Iodargyrite & & & \\
\hline
\end{tabular}
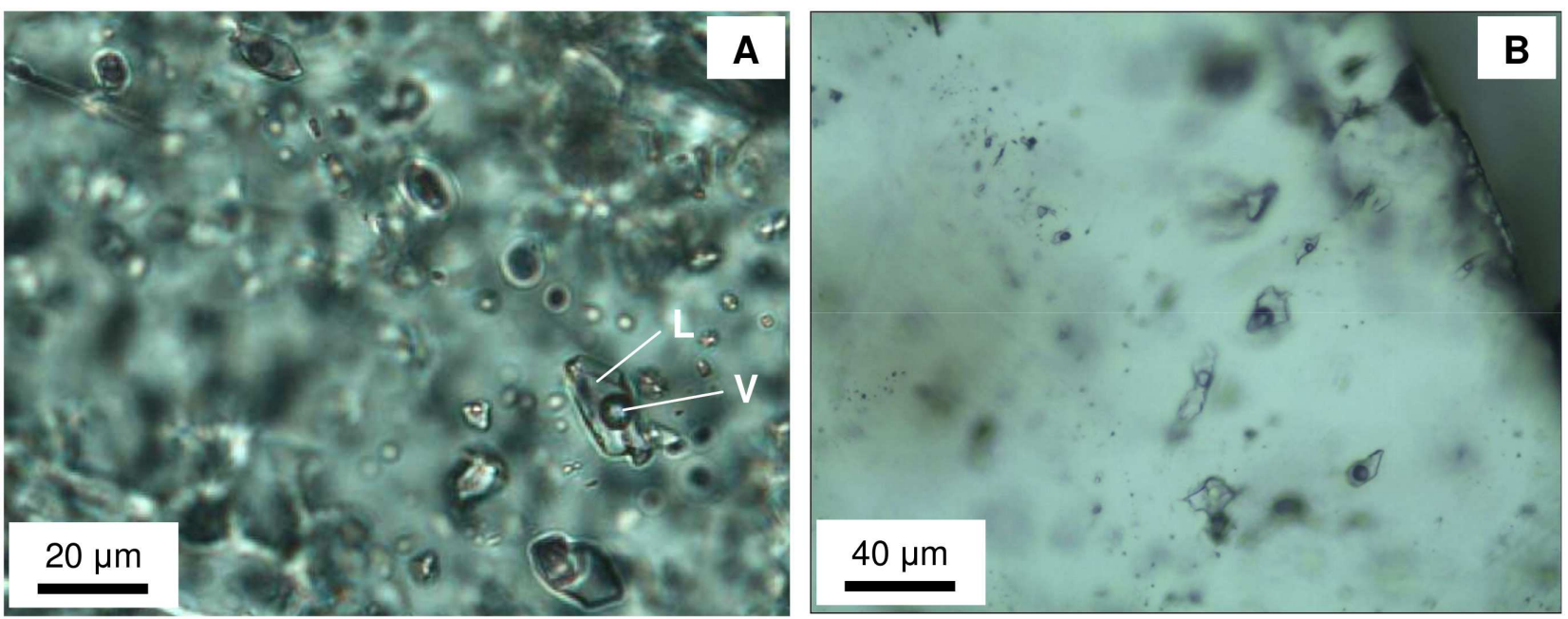

Figure 4: Microphotographs of fluid inclusions trapped in quartz of the Bincanai vein. A. Primary two-phase liquid-vapor (liquid-rich) fluid inclusions in sample WBC.1A.V. B. Primary fluid inclusions spread parallel and clustered around the host quartz crystal fringes (sample TBC.1B) 
NUR et al.

Table 2: Summary of fluid inclusion microthermometry results

\begin{tabular}{lllllll}
\hline Sample & n & Th $\left({ }^{\circ} \mathrm{C}\right)$ & Tm $\left({ }^{\circ} \mathrm{C}\right)$ & $\begin{array}{l}\text { Salinity } \\
\text { (wt.\% } \mathrm{NaCl} \\
\text { eq.) }\end{array}$ & $\begin{array}{l}\text { Formation } \\
\text { temperature } \\
\left({ }^{\circ} \mathrm{C}\right)\end{array}$ & $\begin{array}{l}\text { Salinity (wt.\% NaCl } \\
\text { eq.) of responsible } \\
\text { hydrothermal fluid }\end{array}$ \\
\hline WBC.1A.V & 20 & 208 to 267 & -0.9 to -1.8 & 1.7 to 3.0 & 230 to 240 & 2.0 to 2.5 \\
WBC.3A.V & 22 & 204 to 278 & -1.0 to -1.8 & 1.8 to 3.0 & 230 to 240 & 2.0 to 2.5 \\
TBC.1A & 17 & 192 to 301 & -0.9 to -2.1 & 1.7 to 3.6 & 270 to 280 & 2.0 to 2.5 \\
TBC.1B & 22 & 245 to 305 & -0.9 to -2.0 & 1.7 to 3.3 & 270 to 280 & 2.0 to 2.5 \\
\hline
\end{tabular}

n: number of measurement

higher temperature range represents temperature deposition of the base metal (galena, sphalerite), this is also figured by the higher temperature of the sample TBC.1A and TBC.1B which is $270-280^{\circ} \mathrm{C}$ in peak (Figure $5 \mathrm{C}$ and Table 2); while the lower temperature range is correlate with the precipitation of the rest relatively lower temperature sulphides (chalcopyrite, pyrite, tetrahedrite, tennantite, polybasite, and the $\mathrm{Bi}-\mathrm{Ag}-\mathrm{Cu}-\mathrm{Fe}-\mathrm{bearing}$ sulfide). This sequence is also consistent with the mineral paragenetic described in the previous section (Table 1). The mean of salinity $(2.0-2.5$ wt. $\% \mathrm{NaCl}$ eq.) indicates that fluid responsible for the mineralization in the Bincanai vein is relatively lowsalinity fluid.

\section{Acknowledgements}

The first author wish to express a sincere gratitude to Prof. Koichiro Watanabe at the Department of Earth Resources Engineering, Kyushu University for the permission to conduct the laboratory works. This study was made possible through the financial support from JBIC and JASSO scholarships granted to the first author. We are grateful to PT. Sungai Berlian Bhakti for the access to the exploration site.

\section{References}

Bodnar, R.J. (1993) Revised equation and table for determining the freezing point depression of $\mathrm{H}_{2} \mathrm{O}-\mathrm{NaCl}$ solutions. Geochimica et Cosmochimica Acta, 57, 683-684.

Bodnar, R.J., Reynolds, T.J., and Kuehn, C.A. (1985) Fluid-inclusion systematics in epithermal sys- tems. In Berger, B.R. and Bethke, P.M. (eds.), Geology and geochemistry of epithermal systems, Rev. in Economic Geology, 2, 73-97.

Etoh, J., Izawa, E. and Taguchi, S. (2002) A fluid inclusion study on columnar adularia from the Hishikari low-sulfidation epithermal gold deposit, Japan. Resource Geology, 52, 73-78.

Harijoko, A., Ohbuci, Y., Motomura, Y., Imai, A. and Watanabe, K. (2007) Characteristics of the Cibaliung gold deposit: Miocene low-sulfidation-type epithermal gold deposit in western Java, Indonesia. Resource Geology, 57, 114-123.

Hedenquist, J.W., Arribas, R.A. and GonzalezUrien, E. (2000) Exploration for epithermal gold deposits. Society of Economic Geologists (SEG) Reviews, 13, 245-277.

Marshall, D., Anglin, C.D. and Mumin, H. (2004) Ore mineral atlas. Geological Association of Canada - Mineral Deposits Division, 112 p.

Morrison, G.W., Dong, G., Jaireth, S. (1990) Textural zoning in epithermal quartz veins. Amira Project P247, Gold Research Group, James Cook University of North Queensland, $33 \mathrm{p}$.

Nur, I., Idrus, A., Pramumijoyo, S., Harijoko, A., Juyanagi, Y., Imai, A. (2009) Characteristics of epithermal quartz veins at Baturappe area, Gowa, South Sulawesi, Indonesia: an implication to base metal exploration. Proceedings of the International Conference on Earth Science and Technology, Yogyakarta, Indonesia, 2009, 179-185.

Nur, I., Idrus, A., Pramumijoyo, S., Harijoko, A., Juyanagi, Y., Takahashi, R., Watanabe, K., and Imai, A. (2010) Geochemistry, mineralogy and fluid inclusion study of the Baturappe epithermal silver-base metal deposit, South Sulawesi, Indonesia. Proceedings of the CINEST International Symposium on Earth Science and Technology 2010, Kyushu University, Japan, 283-288.

Nur, I., Idrus, A., Pramumijoyo, S., Harijoko, A., Imai, A., Sufriadin, Irfan, U.R., Astaman, W. and Asmariyadi (2011) Hydrothermal alteration asso- 

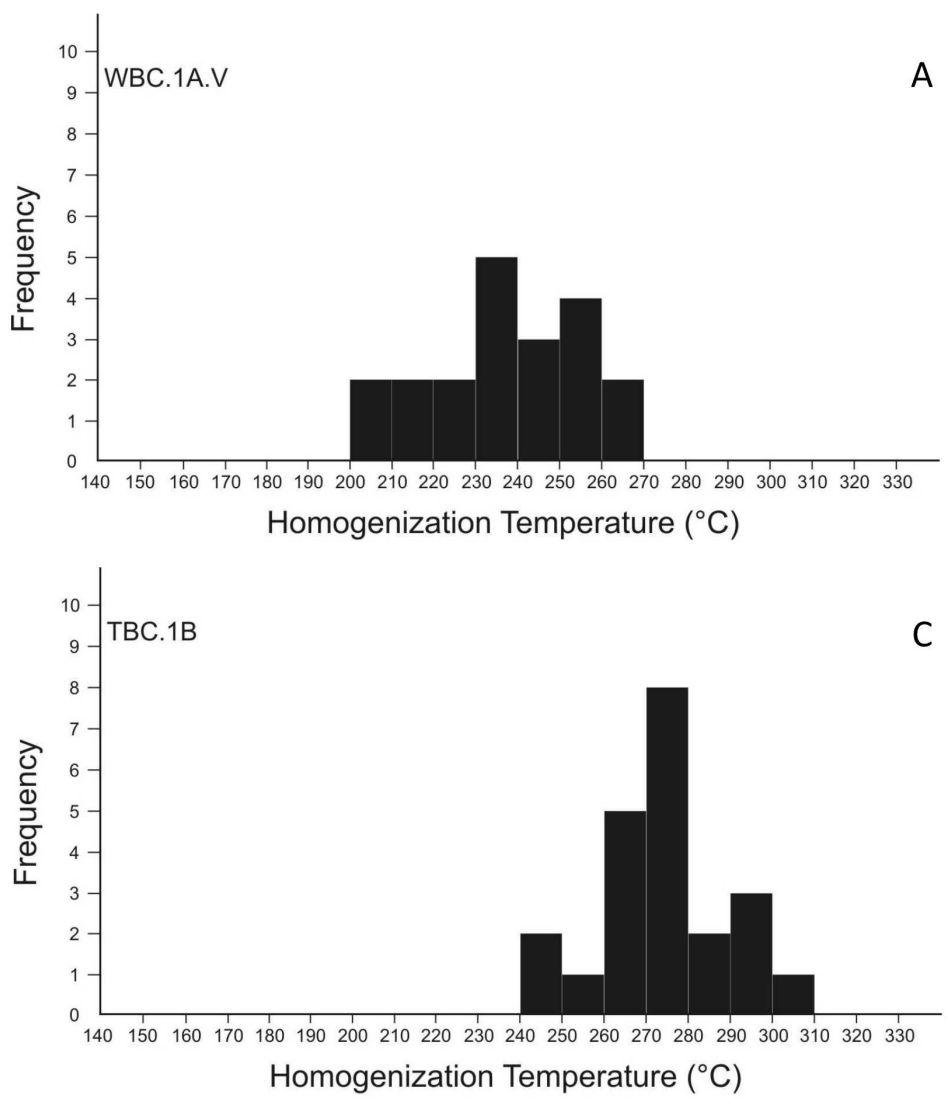
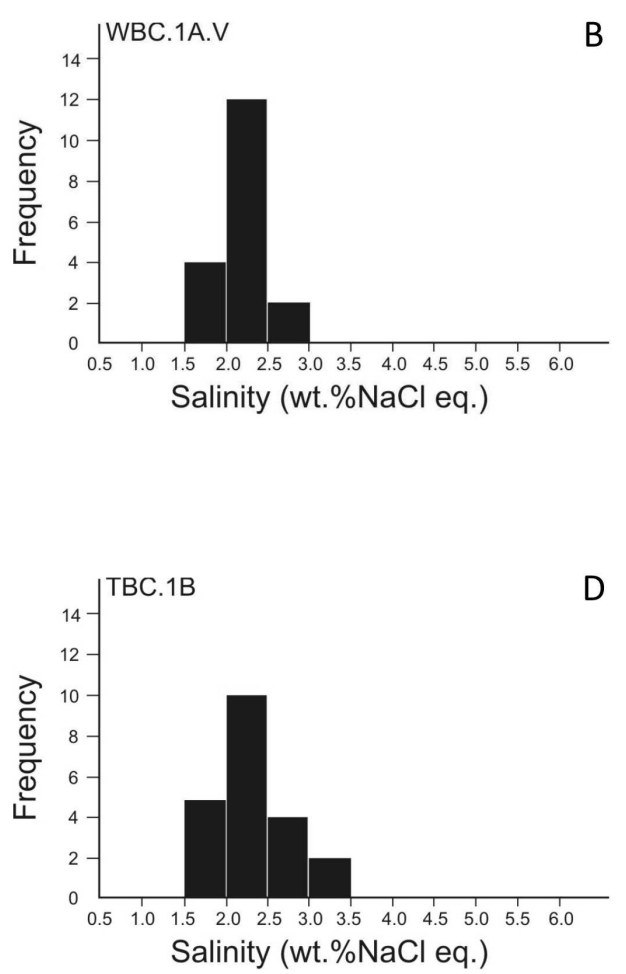

Figure 5: Histograms of fluid inclusion microthermometry results 
ciated with the epithermal $\mathrm{Pb}-\mathrm{Zn}-\mathrm{Cu}-\mathrm{Ag}$ veins at Baturappe area, South Sulawesi, Indonesia: constraint from mineralogical and geochemical data. Proceedings of the Joint Convention HAGI-IAGI 2011, Makassar, Indonesia, paper no. JCM-2011200.

Pracejus, B. (2008) The ore minerals under the microscope, an optical guide. Atlases in Geoscience 3, Elsevier, Netherlands, 875 p.

Priadi, B., Bellon, H., Maury, R.C., Polvé, M., SoeriaAtmadja, R. and Philippet, JC. (1994) Magmatic evolution in Sulawesi in the light of new 40K40Ar age data. Proceedings of PIT IAGI XXIII, 1994, 355-370.

Roedder, E. (1979) Fluid inclusions as samples of ore fluids. In Barnes, H.L. (ed.), Geochemistry of hydrothermal ore deposits, 2nd Edition, John Wiley and Sons, Inc., Canada, 684-737.

Roedder, E. (1984) Fluid inclusions. In Ribbe, P.H. (ed.), Reviews in mineralogy vol.12, Min- eralogical Society of America, BookCrafters, Inc., Chelsea, Michigan, 646 p.

Sillitoe, R.H. and Hedenquist, J.W. (2003) Linkages between volcanotectonic settings, ore-fluid compositions, and epithermal precious metal deposits. Economic Geology, 16, 315-343.

Sukamto, R. and Supriatna, S. (1982) Geologic map of the Ujung Pandang, Benteng and Sinjai quadrangles, Sulawesi. Geological Research and Development Centre, Bandung, Indonesia.

Yuwono, Y.S., Bellon, H., Soeria-Atmadja, R. and Maury, R.C. (1985) Neogene and Pleistocene volcanism in South Sulawesi. In Koesoemadinata, R.P. and Noeradi, D. (eds.), Indonesian island arcs: magmatism, mineralization, and tectonic setting, ITB, 2003, 120-131. 